\title{
Potencjalne zastosowanie terapeutyczne inhibitorów PERK
}

\section{mgr Justyna Basak mgr Wioletta Rozpędek ${ }^{1}$, dr Dariusz Pytel ${ }^{2}$, \\ prof. dr hab. Ireneusz Majsterek $^{1 \bowtie}$}

${ }^{1}$ Uniwersytet Medyczny w Łodzi, Zakład Chemii i Biochemii Klinicznej, Łódź; Polska, ${ }^{2}$ Department of Biochemistry and Molecular Biology, Hollings Cancer Center, Medical University of South Carolina, Charleston, S.C. 29425, USA

$\unrhd_{\text {autor }} \quad$ korespondencyjny: ireneusz. majsterek@umed.lodz.pl

https://doi.org/ 10.18388/pb.2019_262

Słowa kluczowe: stres ER, szlak UPR, PERK, choroby nowotworowe, choroby neurodegeneracyjne, inhibitory PERK

Wykaz skrótów: AD (ang. Alzheimer's disease) - choroba Alzheimera, ATF4 (ang. activating transcription factor 4) - czynnik transkrypcyjny 4, ATF6 (ang. activating transcription factor 6) - czynnik transkrypcyjny 6, BiP (GRP78) (ang. binding immunoglobulin protein) - białko wiążące ciężki łańcuch immunoglobuliny, CHOP (ang. transcription factor C/EBP homologous protein) - czynnik transkrypcyjny, homolog białka C/EBP, eIF2 (ang. eukaryotic translation initiation factor 2) - eukariotyczny czynnik inicjacji translacji 2, ER (ang. endoplasmic reticulum) - retikulum endoplazmatyczne, IRE1 (ang. inositol-requiring protein 1) - białko wymagające inozytol 1, PERK (ang. protein kinase RNA-like ER kinase) - kinaza białkowa retikulum endoplazmatycznego, UPR (ang. Unfolded Protein Response) - szlak adaptacyjnej odpowiedzi na stres

Źródła finansowania: Praca została sfinansowana grantu OPUS nr 2016/21/B/NZ5/01411 przyznanego przez Narodowe Centrum Nauki, OPUS nr 2016/23/B/NZ5/02630 przyznanego przez Narodowe Centrum Nauki, PRELUDIUM nr 2015/19/N/NZ3/00055 przyznanego przez Narodowe Centrum Nauki oraz HARMONIA nr 2013/10/M/NZ1/00280 przyznanego przez Narodowe Centrum Nauki.

\section{STRESZCZENIE}

$\mathrm{O}$ tatnie badania mające na celu poznanie molekularnych mechanizmów chorób człowieka wskazują, iż w patogenezie wielu zaburzeń metabolicznych włączając w to procesy zapalne, starzenie organizmu, a także nowotwory oraz choroby neurodegeneracyjne, znaczącą rolę odgrywa stres retikulum endoplazmatycznego, który jest związany z gromadzeniem się nieprawidłowo sfałdowanych białek $w$ świetle retikulum. $W$ odpowiedzi na stres retikulum endoplazmatycznego indukowany jest szlak adaptacyjnej odpowiedzi na stres, który może pełnić dwojaką rolę. Szlak adaptacyjnej odpowiedzi na stres może przywracać homeostazę w obrębie retikulum poprzez degradację nieprawidłowych białek, hamowanie dalszej translacji i mobilizację białek opiekuńczych, ale może również promować apoptozę w warunkach przedłużającego się stresu retikulum endoplazmatycznego. Szlak adaptacyjnej odpowiedzi na stres rozgałęzia się na trzy odrębne ścieżki sygnałowe, w którym uczestniczą trzy receptory transmembranowe: PERK, IRE1 oraz ATF6. Najbardziej obiecująca dla rozwoju nowych terapii wielu schorzeń człowieka, a w szczególności chorób neurodegeneracyjnych oraz nowotworowych, jest ścieżka związana z PERK, której inhibicja wykazywała pozytywne efekty terapeutyczne zarówno $\mathrm{w}$ badaniach in vitro jak i in vivo.

\section{WPROWADZENIE}

Retikulum endoplazmatyczne (ang. endoplasmic reticulum, ER) jest jednym z kluczowych struktur komórkowych warunkujących zachowanie prawidłowych właściwości i funkcji syntetyzowanych białek [1,2]. Wiele czynników może zaburzać homeostazę w obrębie tego organellum prowadząc do zaburzeń struktury przestrzennej białek, a tym samym wywołując stres ER, co ma istotny wpływ na regulację procesów zachodzących w komórce. Gromadzenie się dysfunkcyjnych białek sprzyja powstawaniu nieprawidłowych interakcji i może prowadzić do rozwoju licznych stanów patologicznych [1,3,4]. Z tego względu stres ER odgrywa znaczącą rolę w patogenezie chorób człowieka, w których angażowane są szlaki związane $\mathrm{z}$ odpowiedzią na stres ER, takich jak choroby zapalne, metaboliczne, nowotworowe oraz neurodegeneracyjne, a także starzenie organizmu $[1,5,6]$. Kluczowym białkiem indukowanym w odpowiedzi na stres ER jest PERK (ang. protein kinase RNA-like ER kinase), której ścieżkę powiązano ze śmiercią komórek $\beta$ trzustki w przebiegu cukrzycy, zaostrzaniem stanu zapalnego w otyłości oraz zwiększaniem stresu oksydacyjnego, co przyczynia się m.in. do nasilenia miażdżycy tętnic [5]. Aktywność PERK może również prowadzić do apoptozy komórek nerwowych prowadząc do neurodegeneracji w schorzeniach takich jak choroba Alzheimera (ang. Alzheimer's disease, AD) czy choroba Parkinsona (ang. Parkinson's disease, PD), a także ułatwiać adaptację i wzrost komórek nowotworowych, dlatego hamowanie ścieżki sygnałowej związanej z PERK w tych jednostkach chorobowych może przynieść korzystne efekty terapeutyczne $[7,8]$.

Choroby nowotworowe oraz neurodegeneracyjne stanowią obecnie dwie najbardziej problematyczne pod względem epidemiologicznym oraz terapeutycznym grupy schorzeń, dlatego rozwój nowych metod leczenia tych schorzeń jest szczególnie ważny $[9,10]$. Choroby neurodegeneracyjne należą do zaburzeń rozwijających się głównie u osób w podeszłym wieku, co jest niezwykle niepokojące, zważywszy na starzejące się społeczeństwa. Patofizjologia tych schorzeń jest bardzo złożona, a podłoże jest w dalszym ciągu niewystarczająco poznane, co znacznie utrudnia opracowywanie skutecznych terapii. Choroby te wiążą się z wysoką liczbą zachorowań i rosnącą śmiertelnością $[9,11]$. Szacuje się, że na AD cierpi 26 milionów osób na świecie, a choroba Parkinsona dotyka obecnie aż 6 milionów osób [3, 11]. Według przewidywań Światowej Organizacji Zdrowia (ang. World Health Organization, WHO) w ciągu dwóch dekad liczba zgonów z powodu schorzeń neurodegeneracyjnych wzrośnie do tego stopnia, iż stanie się drugą najczęstszą przyczyną śmierci zaraz po schorzeniach układu sercowo-naczyniowego [9]. Choroby nowotworowe również stanowią jedną z wiodą- 
cych przyczyną śmierci na świecie. Według danych statystycznych w 2012 r. liczba nowych zachorowań na choroby nowotworowe przekroczyła $14 \mathrm{mln}$, a liczba zgonów z powodu nowotworów w tym czasie szacowana jest na ponad $8 \mathrm{mln}$. Wysoka zachorowalność na choroby nowotworowe związana jest z coraz powszechniejszym nieprawidłowym stylem życia i związanymi z nim czynnikami ryzyka, takimi jak niewłaściwa dieta, palenie tytoniu oraz niska aktywność fizyczna $[10,12]$.

\section{STRES ZWIĄZANY Z RETIKULUM ENDOPLAZMATYCZNYM}

Retikulum endoplazmatyczne stanowi rozbudowany system kanalików, cystern oraz pęcherzyków odizolowanych błonami od środowiska cytozolu i rozciągających się po całej komórce $[1,13,14]$. Charakteryzuje się również heterogenną strukturą zróżnicowaną na domeny: gładką, szorstką, regiony kontaktujące się $\mathrm{z}$ innymi organellami oraz domenę otoczki jądrowej [14]. Gładkie ER (ang. smooth endoplasmic reticulum, SER) jest odpowiedzialne za utrzymanie homeostazy wapnia w komórce, metabolizm węglowodanów, detoksykację leków oraz produkcję kwasów tłuszczowych, steroidów i fosfolipidów [14-16]. Stężenie jonów $\mathrm{Ca}^{2+}$ we wnętrzu ER jest dużo wyższe w stosunku do cytoplazmy, dlatego uważa się, że wapń może mieć istotne znaczenie dla wielu procesów zachodzących w świetle ER, jak i w komórce, gdy dochodzi do jego uwalniania do cytoplazmy $\mathrm{w}$ procesie sygnalizacji komórkowej [1,17].

Szorstkie ER (ang. rough endoplasmic reticulum, RER), w przeciwieństwie do gładkiego, charakteryzuje się obecnością rybosomów [16]. Struktura ta pełni ważną rolę w syntezie i procesie zwijania białek, a także transporcie wewnątrzkomórkowym i zewnątrzkomórkowym białek oraz modyfikacjach potranslacyjnych takich jak obróbka proteolityczna czy glikozylacja [15,17-19]. Prawidłowe funkcje RER utrzymywane są dzięki silnie utleniającym warunkom, co jest konieczne do tworzenia mostków disiarczkowych istotnych dla formowania trzeciorzędowej struktury białek oraz dzięki aktywności licznych białek opiekunczych, tzw. chaperonów, które wiążą częściowo złożone białka i zapobiegają ich nieprawidłowej agregacji $[1,15]$. W proces składania białek zaangażowane są takie chaperony jak białko wiążące ciężki łańcuch immunoglobuliny (ang. binding immunoglobulin protein, BiP lub GRP78) oraz endoplazmina, a także białka uczestniczące w składaniu glikoprotein, takie jak kalneksyna i kalretikulina [20]. Procesy zachodzące w obrębie retikulum są kluczowe dla białek wydzielniczych, które po syntezie na rybosomach transportowane są do ER, gdzie ulegają obróbce i składaniu w kompleksy wyższego rzędu przed kolejnym etapem modyfikacji zachodzącym w aparacie Golgiego (AG) $[19,21]$. ER odpowiada za zachowanie homeostazy komórkowej poprzez kontrolowanie tego jakie białka dostają się do AG oraz swoich docelowych lokalizacji w komórce [19]. Nieprawidłowo sfałdowane białka oddziałują z odpowiednimi chaperonami, a następnie są transportowane do cytoplazmy i ubikwytynylowane, dzięki czemu są usuwane $\mathrm{w}$ proteasomie $\mathrm{w}$ procesie degradacji białek związanej z ER (ang. ER-associated degradation, ERAD) $[20,22,23]$.
Liczne czynniki, zarówno fizjologiczne, jak i patologiczne mogą zmieniać środowisko w świetle ER, zaburzając funkcje ER i prowadząc do gromadzenia się nieprawidłowo sfałdowanych lub rozfałdowanych białek w jego obrębie, co określane jest mianem stresu ER [15,18,19]. Charakterystyczne dla tego stanu jest także uwolnienie zmagazynowanych jonów $\mathrm{Ca}^{2+} \mathrm{z}$ wnętrza ER do cytoplazmy oraz zaburzenia w metabolizmie lipidów [24]. Stres ER fizjologicznie może występować w przypadku zmian potencjału redoks, obniżenia poziomu wapnia lub nadprodukcji białek. Do takich zmian dochodzi np. w wyniku dużego zapotrzebowania na produkcję białek, niskiego poziomu energetycznego komórki lub wystąpienia hipoksji. Stres ER może być także indukowany lekami, które m.in. mogą wywoływać zmianę poziomu wapnia czy potencjału redoks, a także występować w stanach patologicznych, w których dochodzi do defektu w ścieżkach sygnałowych odpowiedzialnych za wykrywanie i neutralizowanie stresu ER [1].

\section{SZLAK ADAPTACYJNEJ ODPOWIEDZI NA STRES}

Stres ER wykrywany jest przez specyficzne sensory, które angażują kolejne elementy kaskady sygnałowej przywracającej homeostazę [1]. Uruchamiany jest wówczas szlak adaptacyjnej odpowiedz na stres (ang. Unfolded Protein Response, UPR), którego podstawową rolą jest podtrzymanie przeżycia komórki i przywrócenie równowagi w obrębie ER poprzez ograniczenie gromadzenia się białek o nieprawidłowej strukturze przestrzennej $[15,16,19]$. Kluczowym elementem mechanizmu obronnego ER jest zahamowanie syntezy większości białek, mobilizacja białek opiekuńczych oraz degradacja białek wadliwych w szlaku ERAD [19,22]. Badania wskazują, iż szlak UPR może pełnić dwojaką rolę i w niektórych przypadkach prowadzić do apoptozy komórek [22]. Nasilony, przedłużający się stres ER może prowadzić do przełączenia szlaku UPR z pro-adaptacyjnej do pro-apoptotycznej postaci $[5,7]$. Przedłużające się warunki stresu w obrębie ER mogą także aktywować stan zapalny w sąsiednich komórkach, który zapobiega większemu uszkodzeniu tkanki [24].

Szlak UPR rozgałęzia się na trzy odrębne drogi sygnałowe, w których uczestniczą trzy główne białka transmembranowe: PERK, białko IRE1 (ang. inositol-requiring protein 1a) oraz czynnik transkrypycjny ATF6 (ang. activating transcription factor 6) $[13,24]$. Dokładny mechanizm aktywacji szlaku UPR nie został jeszcze poznany, jednak wiadomo, że białka opiekuńcze, takie jak białko BiP są zaangażowane w aktywację triady sygnałowej IRE1, ATF6, PERK [24]. W warunkach prawidłowych białko BiP wiąże sensory stresu ER, inaktywując je. Akumulacja nieprawidłowo sfałdowanych białek powoduje odłączenie BiP od receptorów IRE1, ATF6 oraz PERK, powodując ich aktywację [20,25]. ATF6 należy do rodziny białek zawierających domenę zamka leucynowego, z C-końcowym fragmentem zlokalizowanym w świetle ER i N-końcem zanurzonym w cytoplazmie $[16,26]$. W warunkach homeostatycznych ATF6 jest częściowo zoligomeryzowany, natomiast pod wpływem czynników stresowych wiązania disiarczkowe, które wiążą monomery ATF6, ulegają osłabieniu, prowadząc do przekształcenia ATF6 w postać monomeryczną (ATF6N) [27]. Ponadto po odłącze- 
niu białka BiP zostają odsłonięte sygnały lokalizacji AG [16]. ATF6 ulega translokacji do AG, gdzie pod wpływem proteaz S1 (ang. site 1 protease) oraz S2 (ang. site 2 protease) zostaje odszczepiona jego cytoplazmatyczna domena, będąca aktywnym czynnikiem transkrypcyjnym. Po odłączeniu od transbłonowej kotwicy część cytoplazmatyczna ATF6 może przemieścić się do jądra, gdzie włącza transkrypcję genów zaangażowanych w szlak pro-adaptacyjny UPR, takich jak białka opiekuńcze BiP, a także foldazy uczestniczące $\mathrm{w}$ reakcjach nadających białkom odpowiednią konformacje $[20,24,27,28]$. Jednym z genów pozytywnie regulowanych przez ATF6 jest gen białka wiążącego X-box-1 (ang. X-box binding protein-1, XBP1), który ulega następnie obróbce przez IREa. Aktywny ATF6 może również regulować ekspresję genów szlaku ERAD [20].

IRE1 jest dwufunkcyjnym enzymem o aktywności zarówno białkowej kinazy serynowo-treoninowej, jak i endorybonukleazy [20]. Podczas stresu ER, IRE1 ulega dimeryzacji, a następnie autofosforylacji, co aktywuje funkcje nukleazy [27]. IRE1 jest odpowiedzialny za hamowanie transkrypcji genów kodujących białka zlokalizowane w ER oraz obróbkę transkryptu XBP1u, z którego w alternatywnym splicingu zostaje wycięty jeden intron. W wyniku obróbki XBP1u dochodzi do zmiany ramki odczytu i utworzenia silnego aktywatora transkrypcji XBP1s $[20,22,24]$. XBP1s nasila ekspresję licznych genów szlaku UPR, przede wszystkim chaperonów, a także białek zaangażowanych w szlak
ERAD, lipogenezę oraz apoptozę, np. pro-apoptotycznego białka CHOP (ang. transcription factor C/EBP homologous protein) $[28,29]$. PERK jest aktywowana w podobny sposób do białka IRE1, jednak jej aktywacja wyzwala inny efekt [24]. N-końcowa domena PERK znajduje się w świetle ER i w prawidłowych warunkach jest inaktywowana poprzez związanie z BiP. Pod wpływem stresu ER, uwolniona od białka BiP, PERK ulega oligomeryzacji, a następnie autofosforylacji w C-końcowej domenie cytoplazmatycznej [16,27]. Substratem aktywowanej PERK jest reszta seryny w pozycji 51 podjednostki a eukariotycznego czynnika inicjacji translacji eIF2 (ang. eukaryotic translation initiation factor 2), który wiąże guanozyno-5' -trifosforan (GTP) oraz inicjatorową cząsteczkę metionylo-tRNA i jest odpowiedzialny za transport inicjatorowego metionylo-tRNA do małej podjednostki rybosomu $\mathrm{W}$ procesie inicjacji translacji $[22,24]$. Po rozpoczęciu translacji, związany z eIF2a, GTP ulega hydrolizie do GDP, dzięki aktywności czynnika wymiany nukleotydów guaninowych związanego z podjednostką $\beta$ czynnika eIF2. Wymiana ta jest konieczna dla odnowienia eIF2a i wznowienia cyklu inicjacji translacji [22]. W ufosforylowanym czynniku eIF2a wymiana nukleotydów jest niemożliwa, co wstrzymuje proces tworzenia kompleksu inicjacji translacji i powoduje zmniejszenie wydajność odczytu kodonu startowego AUG w transkryptach większości białek, tym samym zmniejszając obciążenie ER poprzez obniżenie poziomu translacji $[20,22]$. Transkrypty kodujące niektóre białka posiadają krótkie otwarte ramki odczytu w nieule-

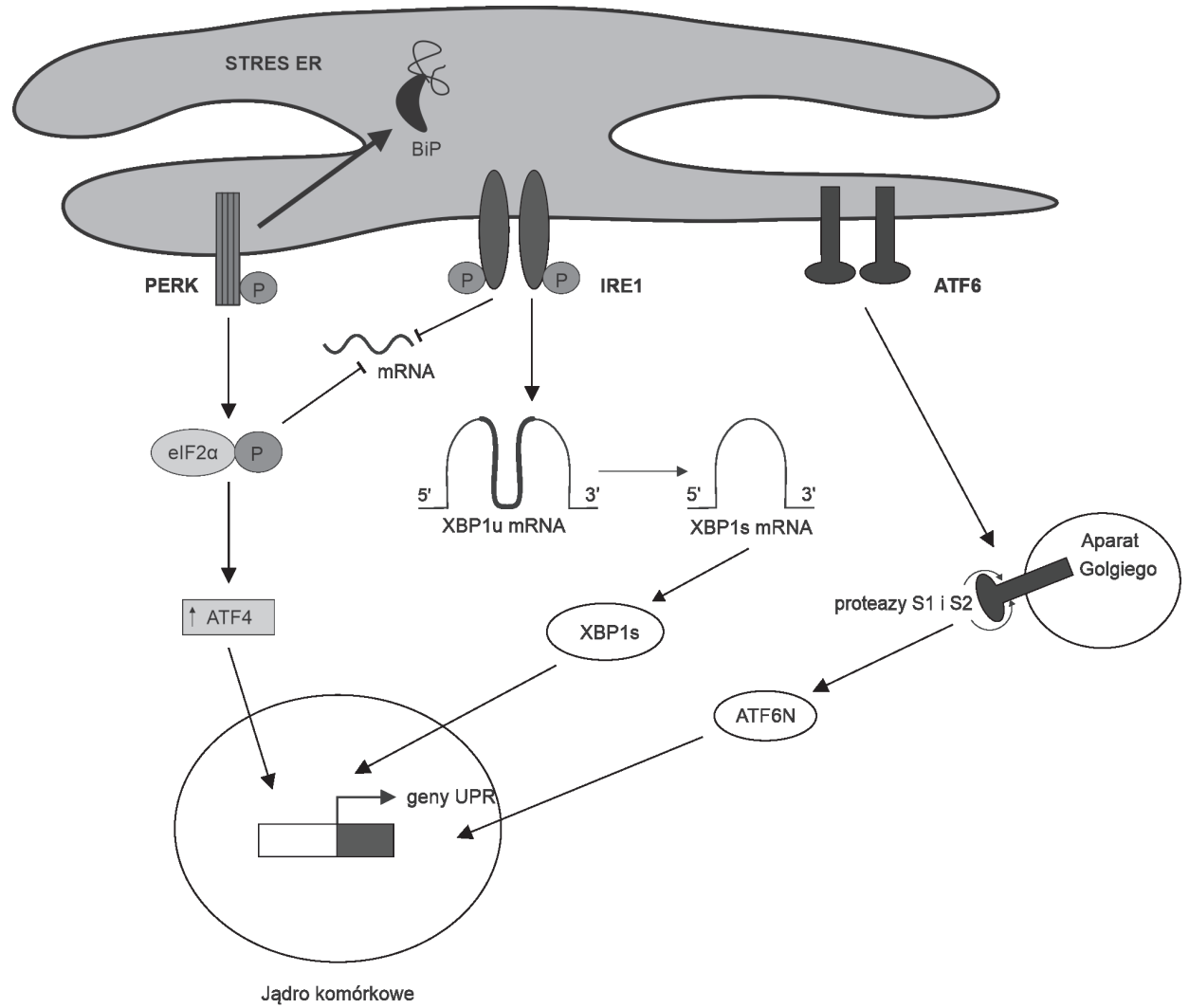

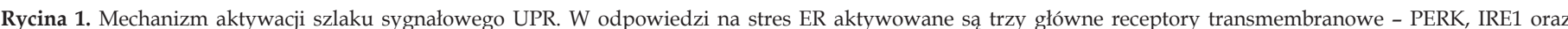

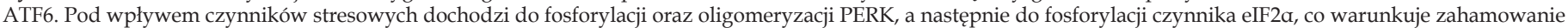

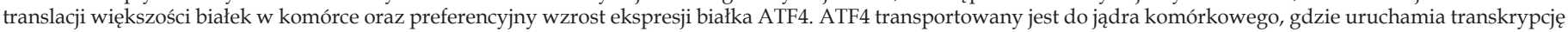

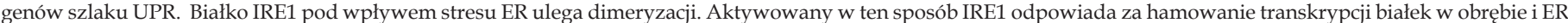

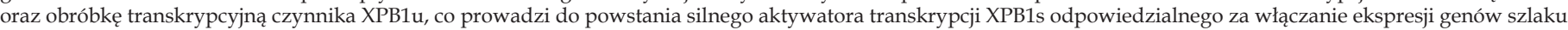

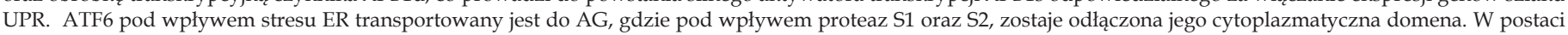
monomeru (ATF6N) transportowany jest do jądra komorowego gdzie, jako aktywny czynnik transkrypcyjny włącza ekspresję genów szlaku UPR. 
gającym translacji regionie $5^{\prime}$ stanowiące blok translacyjny, tzw. wewnętrzne miejsce wiązania rybosomu (ang. internal ribosome entry site, IRES), które mogą zostać pominięte tylko gdy eIF2a jest ufosforylowany. Fosforylacja czynnika eIF2a prowadzi więc do preferencyjnej syntezy niektórych białek $[14,16,20,24]$. Do kluczowych białek, których synteza uruchamiana jest w ten sposób należy białko ATF4 (ang. activating transcription factor 4), będące czynnikiem transkrypcyjnym kolejnych genów zaangażowanych w szlak UPR (Ryc. 1). Co istotne, ATF4 może indukować ekspresję zarówno genów związanych z autofagią oraz apoptozą, takich jak białko CHOP, jak i genów odpowiedzialnych za odpowiedź przeciwutleniająca czy też wyciszanie szlaku UPR po przywróceniu homeostazy. Do kluczowych genów kontrolujących zahamowanie kaskady sygnałowej UPR należy GADD34 (ang. growth arrest and DNA damage-inducible), kodujący podjednostkę PP1C fosfatazy białkowej, która defosforyluje eIF2a i przywraca zahamowaną dotychczas translację $[1,27,29]$.

\section{INDUKCJA APOPTOZY W SZLAKU UPR}

Apoptoza jest procesem programowanej śmierci komórki, której głównym celem jest utrzymanie homeostazy organizmu. Programowana śmierć komórki zachodzi selektywnie tylko w komórkach nadmiernie uszkodzonych, które zagrażają całemu organizmowi [15]. W przebiegu apoptozy obserwuje się wiele zmian morfologicznych i biochemicznych, takich jak: zmniejszanie objętości komórek, kondensacja chromatyny, zmiany w obrębie zewnętrznej błony mitochondrialnej, odizolowanie fragmentów komórki w postaci ciałek apoptycznych, uszkodzenia i degradacja DNA oraz proteoliza białek [22,30]. Zaburzenia błony mitochondrialnej są główną przyczyną uwalniania czynników pro-apoptotycznych, które z kolei aktywują kaspazy, będące głównymi białkami zaangażowanymi w szlak apoptotyczny [22]. Kaspazy, zaliczane do enzymów proteolitycznych, syntetyzowane są jako nieaktywne prokaspazy i ulegają kaskadowej aktywacji. Ze względu na rolę jaką pełnią kaspazy w przekazie sygnału i wywoływaniu efektów szlaku apoptotycznego, wyróżnia się kaspazy inicjujące, takie jak kaspazy 8, 9 i 12, które są aktywne na początkowych etapach kaskady, a także kaspazy efektorowe, do których zalicza się kaspazy 3, 7 i 9. Do najważniejszych czynników regulujących apoptozę i aktywujących kaspazy inicjujące należą białka $\mathrm{z}$ rodziny Bcl-2 (ang. B-cell lymphoma 2) zawierające tzw. domeny homologii BH (ang. Bcl-2 homology). Rodzina ta obejmuje zarówno białka pro- jak i anty-apoptotyczne. Część białek rodziny Bcl-2 promujących apoptozę (Bax, Bok oraz Bak) zawiera trzy domeny $\mathrm{BH}$ (BH1-BH3), jednak niektóre takie jak Bim, Bax, Noxa oraz Puma posiadają tylko jedną domenę (BH3) (BH3-only) [15]. Rodzina Bcl-2 jest związana $\mathrm{z}$ wewnętrzną błoną mitochondrialną. Białka o charakterze pro-apoptotycznym rodziny Bcl-2 promują uwalnianie cytochormu c do cytoplazmy poprzez pory w błonie mitochondrialnej powstałe wskutek jej permeabilizacji. W przeciwieństwie do nich, anty-apoptotyczna część rodziny Bcl-2, do której należą m.in. białka Bcl-1, Bcl-2 oraz Bcl-W, hamuje uwalnianie cytochromu c prowadząc do supresji apoptozy $[15,22]$. Białka zawierające tylko domenę BH3 mogą wiązać białka anty-apoptotyczne nie dopuszczając do zahamowania szlaku apoptotycznego. Uwolnienie cytochromu c wskutek zwiększenia przepuszczalności błony mitochondrialnej jest kluczowym elementem wewnętrznego szlaku apoptozy i prowadzi do aktywacji kompleksu aktywującego kaspazę 9, tzw. apoptosomu. Aktywowana kaspaza 9 przeprowadza następnie trawienie prokaspazy 3, a powstała kaspaza 3 stanowi główny efektor szlaku apoptotycznego i jest bezpośrednio odpowiedzialna za śmierć komórek na drodze apoptozy [15].

Białka zaangażowane w regulację aktywności kaspaz są ściśle powiązane z funkcjonowaniem ER, ponieważ zlokalizowane są nie tylko w błonie mitochondrialnej, ale również w domenie otoczki jądrowej ER. Wyciekanie jonów $\mathrm{Ca}^{2+}$ ze światła ER do cytoplazmy, które zachodzi w warunkach stresu ER, może przyczyniać się do aktywacji kaskady kaspaz $[15,31]$. Ponadto białka zawierające domenę BH3 związane z błoną ER mogą aktywować Bax/Bak, które z kolei wyzwalają wyciek jonów $\mathrm{Ca}^{2+}$ [15]. Mimo to dokładny mechanizm przełączenia pro-życiowej ścieżki szlaku UPR na drogę związaną z indukcja apoptozy wciąż pozostaje niejasny [13]. Wiadomo, że CHOP jest głównym białkiem związanym z pro-apoptotyczną funkcją UPR i może indukować apoptozę na kilka różnych sposobów [15,20]. Jego ekspresja jest niska w warunkach homeostatycznych i ulega zwiększeniu pod wpływem głównych sensorów szlaku UPR, przede wszystkim białka PERK. Badania na liniach komórkowych potwierdzają udział białka CHOP w indukcji apoptozy związanej z UPR. Komórki z nadekspresją białka CHOP ulegały apoptozie, natomiast komórki z wyciszonym genem CHOP były odporne na apoptozę wywoływaną stresem ER [32]. Mechanizm indukcji apoptozy przez CHOP związany jest ze zmianą regulacji białek z rodziny Bcl-2. Aktywność CHOP prowadzi do obniżenia poziomu białka Bcl2 i zwiększenia poziomu transkrypcji genów kodujących białka zawierających domenę BH3, takich jak Bim, Bax oraz Puma [16,32]. CHOP indukuje również ekspresję genów z rodziny receptorów śmierci DR5 [32]. Nadekspresja CHOP związana jest także z aktywacją GADD34, co przy przywróceniu równowagi w ER jest procesem korzystnym, jednak gdy czynniki wyzwalające stres są nadal obecne, prowadzi do jeszcze większego obciążenia ER, a więc sprzyja wejściu komórki na drogę apoptozy [15,33].

Indukcja apoptozy przez białko CHOP związana może być również $\mathrm{z}$ nasileniem stresu oksydacyjnego. $\mathrm{CHOP}$ zwiększa wydzielanie reaktywnych form tlenu (ang. reactive oxygen species, ROS) i obniża poziom antyoksydacyjnego glutationu w komórce. Ponadto CHOP jest czynnikiem promującym ekspresję ERO1a (ang. ER oxidoreductin 1 a). ERO1a katalizuje reoksydację izomerazy wiązań disiarczkowych (ang. protein disulfide isomerase, PDI) [32,34]. Izomeraza ta jest odpowiedzialna za syntezę wiązań disiarczkowych w białkach, dlatego prawdopodobnie przy długo utrzymującym się stresie ER przyczynia się do wzmożonej produkcji nadtlenku wodoru. ERO1a aktywuje również kanały wapniowe zlokalizowane w błonie ER (ang. inositol 1,4,5-trisphosphate receptor 1, IP3R1). Uwolnione $\mathrm{z}$ ER na skutek otwarcia kanałów IP3R1 jony $\mathrm{Ca}^{2+}$ aktywują kinazę białkową zależną od kompleksu wapń-kalmodulina (ang. $\mathrm{Ca}^{2+} / \mathrm{calmodulin-de-}$ pendent protein kinase II, CaMKII), co z kolei prowadzi do uruchomienia dalszych czynników szlaku apoptotycznego $[15,32]$. Szlak związany z CaMKII powoduje także aktywa- 
cję błonowej oksydazy NADPH2 (ang. NADPH oxidase subunit 2, NOX2), której aktywność generuje ROS. Co istotne, wytwarzane w ten sposób ROS w pozytywnym sprzężeniu zwrotnym zwiększają aktywację CaMKII [15].

Apoptoza będąca skutkiem nasilonego stresu ER może być również wywoływana bezpośrednio przez IRE1, który może aktywować kaspazy 4 i 12 oraz tworzyć kompleks z TRAF2 (ang. TNF receptor-associated factor 2) i kinazą 1 regulującą apoptozę (ang. apoptosis signal-regulating kinase 1, ASK1 lub MAPKKK5), a także aktywować JNK (ang. JUN N-terminal kinase), co wzmaga apoptozę w wyniku aktywacji licznych szlaków sygnałowych $[20,28]$. RNazowa aktywność IRE1 może także powodować degradację niektórych mikro RNA, które hamują translację kaspazy 2. Wskutek tego poziom kaspazy 2 znacznie wzrasta, co inicjuje wewnętrzny szlak apoptotyczny [28].

\section{OBECNIE STOSOWANE STRATEGIE TERAPEUTYCZNE W LECZENIU CHORÓB NEURODEGENERACYJNYCH}

Leczenie chorób neurodegeneracyjnych jest szczególnie trudne ze względu na szerokie spektrum procesów patologicznych oraz zmian w metabolizmie komórkowym, a także złożoność układu nerwowego i niepełne zrozumienie ich etiologii. Terapia farmakologiczna jest również utrudniona $\mathrm{z}$ powodu obecności bariery krew-mózg, która ogranicza przenikanie substancji leczniczych do mózgu [35]. Obecnie stosowane leczenie jest jedynie objawowe i opiera się wyłącznie na poprawie jakości życia pacjenta. Terapia chorób neurodegeneracyjnych obejmuje także metody niefarmakologiczne, takie jak rehabilitacja poznawcza pacjenta, terapie zajęciowe, zastosowanie odpowiedniej diety oraz fizykoterapię $\mathrm{w}$ przypadku występowania zaburzeń ruchowych [11]. Farmakologiczna terapia chorób neurodegeneracyjnych opiera się na zastosowaniu inhibitorów acetylocholinoesterazy, zwiększających poziom acetylocholiny w szczelinie synaptycznej. W terapii parkinsonizmu stosuje się leki wzmacniające działanie dopaminy, takie jak agoniści dopaminy oraz lewodopa [11,36,37]. Leczenie niektórych chorób neurodegeneracyjnych może obejmować również zastosowanie selektywnych inhibitorów wychwytu zwrotnego serotoniny (ang. selective serotonin reuptake inhibitors, SSRI) [11]. Standardowe metody leczenia często charakteryzują się bardzo niską skutecznością oraz wywołują liczne skutki uboczne, dlatego konieczne jest opracowanie efektywnej strategii terapeutycznej w leczeniu chorób neurodegeneracyjnych działającej już na podłożu molekularnym [11,36].

Patogeneza wielu chorób neurodegeneracyjnych, takich jak AD, PD a także pląsawicy Huntingtona (ang. Huntington's disease, HD), związana jest przede wszystkim z odkładaniem się nieprawidłowo sfałdowanych agregatów białek w obrębie układu nerwowego, czego skutkiem są zaburzenia w jego funkcjonowaniu, stan zapalny, utrata połączeń synaptycznych, a ostatecznie degeneracja komórek nerwowych $[36,38,39]$. W przypadku $\mathrm{AD}$, charakteryzującej się spadkiem funkcji poznawczych oraz zapaleniem neuronalnym, dochodzi do akumulacji w układzie limbicznym oraz korze nowej mózgu złogów amyloidu- $\beta$ (A $\beta)$ oraz białka tau. Białka te odkładane są w pozakomórkowych blaszkach amyloidowych oraz wewnątrzkomórkowych splątkach neurofibrylarnych $[36,38,40]$. W przebiegu choroby Parkinsona gromadzone jest białko a-synukleina (a-syn), które jest głównym składnikiem ciał Lewy'ego, patologicznych struktur charakterystycznych dla PD $[38,41]$. Gromadzone w przebiegu tych chorób nieprawidłowo złożone agregaty wykazują się wysoką neurotoksycznością, jak również wywierają negatywny wpływ na przepuszczalność błon komórkowych, zmiany w gospodarce jonów $\mathrm{Ca}^{2+}$ oraz zaburzenia transkrypcji genów, aktywności mitochondrialnej i transportu endosomalnego. Z tego względu obecnie stosowane strategie leczenia chorób neurodegeneracyjnych skupiają się przede wszystkim na zapobieganiu agregacji białek zaangażowanych w etiologię danego schorzenia oraz hamowaniu ich syntezy [38].

Przegląd literaturowy wskazuje na skuteczność zastosowania małych interferujących RNA ang. (small interfering $R N A$, siRNA) w wyciszaniu genów zaangażowanych w patogenezę schorzeń neurodegeneracyjnych [39,41]. W przypadku HD zastosowanie terapii genowej ma szczególne uzasadnienie, gdyż przyczyną rozwoju choroby jest mutacja genu kodującego białko huntingtyny (HTT), polegająca na ekspansji kodonu CAG, która prowadzi do syntezy nieprawidłowej, długiej cząsteczki poliglutaminy (PolyQ) [36,39]. Także w patogenezie PD zidentyfikowano mutacje zmiany sensu oraz mutacje wpływające na zwiększenie kopii genu. Mutacja w genie a-synukleiny (SNCA) została uznana jako mechanizm nadekspresji białka i może być poddana terapeutycznemu wyciszaniu [41]. W związku z tym, jako potencjalną metodę leczenia PD można zastosować siRNA w tzw. kompleksach wyciszających RISC (ang. RNA induced silencing complex), które wyciszają gen $S N C A$ poprzez wiązanie do docelowych, komplementarnych sekwencji mRNA, które następnie ulegają cięciu endonukleolitycznemu [40,41]. Również w etiologii AD znaczny udział ma podłoże genetyczne. Rodzinnie występujące przypadki AD związane są m.in. $\mathrm{z}$ mutacjami w obrębie genu kodującego prekursorowe białko amyloidu (ang. amyloid precursor protein, APP), dlatego terapia genetyczna skupiająca się na wyciszaniu genu APP może wykazywać pozytywne efekty [40]. Strategie terapeutyczne mające na celu ograniczenie ilości gromadzonych neurotoksycznych białek wykorzystują również enzymy proteolityczne, spośród których na szczególną uwagę zasługują kalikreiny, należące do głównych proteaz serynowych ośrodkowego układu nerwowego, a także neprylizyna, która jest najważniejszym enzymem warunkującym obróbkę proteolityczną amyloidu $\beta[38,42,43]$. Kalikreina 6 (KLK6) może stanowić potencjalny cel terapeutyczny PD, a także innych chorób neurodegeneracyjnych, gdyż zdolna jest do degradacji a-synukleiny, lamininy, kolagenu oraz prekursorowego białka amyloidu [42]. Ze względu na nieprawidłową agregację białek zaangażowanych $\mathrm{w}$ procesy neurodegeneracyjne skuteczne metody leczenia mogą obejmować także zastosowanie białek opiekuńczych regulujących łączenie poszczególnych podjednostek oraz białka zapobiegające agregacji lub polifenole, które mogą hamować łączenie filamentów a-synukleiny [38,44,45]. 


\section{OBECNIE STOSOWANE STRATEGIE TERAPEUTYCZNE W LECZENIU CHORÓB NOWOTWOROWYCH}

Ze względu na wysokie koszty opracowywania nowych terapii przeciwnowotworowych, leczenie chorób nowotworowych związane jest $\mathrm{z}$ dużym obciążeniem ekonomicznym. Ponadto większość typów nowotworów z wyjątkiem zdiagnozowanych na wczesnych stadiach, a także niektórych typów białaczki, chłoniaka oraz raka jądra jest nieuleczalna, a stosowane terapie stają się nieskuteczne po dłuższym czasie leczenia, dlatego obecnie wykorzystywane metody skupiają się najczęściej na wydłużaniu i podtrzymywaniu życia pacjenta, a nie eliminowaniu choroby [46]. Terapie, które wykazują się wysoką skutecznością i powodują wzrost przeżywalności chorych, wiążą się z wieloma długoterminowymi, niekorzystnymi skutkami dla pacjenta, takimi jak rozwój chorób sercowo-naczyniowych u osób poddanych radioterapii, które mogą doprowadzić do śmierci pacjenta nawet po wyleczeniu choroby nowotworowej [47]. Stosowanie chemioterapii może być także powiązane $\mathrm{z}$ występowaniem takich efektów niepożądanych jak nudności, zaburzenia nastroju i osłabienie apetytu [48]. Natomiast leczenie operacyjne niejednokrotnie wiąże się z powikłaniami, takimi jak bóle, nietrzymanie moczu, zaburzenia funkcjonowania narządu, który podlegał operacji. Powikłania pooperacyjne mogą obniżać jakość życia pacjenta i upośledzać jego funkcjonowanie w społeczeństwie [49,50].

Terapia chorób nowotworowych uzależniona jest od typu nowotworu, a także od stadium choroby i lokalizacji guza, jeśli występuje. Często nawet zbliżone pod względem podłoża molekularnego nowotwory wymagają odrębnego leczenia. Podstawową metodą leczenia wielu typów nowotworów, np. raka jelita grubego, raka prostaty, piersi, przełyku oraz nowotworów układu nerwowego, są operacje chirurgiczne [49,51,52]. Skuteczność tej metody zależy od wielu czynników, takich jak rodzaj przeprowadzonej operacji, jakość operacji oraz właściwa ocena zaawansowania choroby. Przy wyborze leczenia operacyjnego jako terapii podstawowej bierze się pod uwagę wiele czynników takich jak: wiek i sprawność fizyczna pacjenta, występowanie chorób współistniejących, stadium i stopień odróżnicowania nowotworu oraz dalsze rokowania i ryzyko nawrotu $[49,53]$. Oprócz operacji chirurgicznych powszechnie stosowane jest również leczenie ogólnoustrojowe, tzw. neoadiuwantowe, obejmujące najczęściej radioterapię oraz chemioterapię. Leczenie neoadiuwantowe jest dużą skutecznością stosowane w celu redukcji guzów, hamowaniu mikroprzerzutów i zmniejszaniu częstości nawrotów choroby $[49,51]$. Terapia neoadiuwantowa odgrywa istotną rolę w leczeniu kilku typów nowotworów, w tym piersi, jelita grubego, pęcherza moczowego, płuc oraz przełyku [51,54]. Chemioterapia lub radioterapia może także stanowić podstawę leczenia, co ma miejsce w przypadku takich postaci nowotworu przy których resekcja jest niemożliwa lub bardzo utrudniona. W tym celu chemioterapia stosowana jest m.in. w przypadku drobnokomórkowego raka płuc, który często przybiera postać rozsianą [55]. W raku piersi w zależności od częstości nawrotów stosuje się chemioterapię lub terapię z zastosowaniem hormonów. Hormonoterapia wykorzystywana jest do leczenia pacjentek $\mathrm{z}$ rakiem piersi, które mają niski wskaźnik nawrotów. Celem terapii hormonalnej jest w tym przypadku hamowanie interakcji między estrogenami a zależnymi od nich szlakami stymulacji komórek nerwowych [56].

Obok leczenia chirurgicznego, chemioterapii i radioterapii jedną z podstawowych metod walki z chorobami nowotworowymi jest silnie rozwijająca się obecnie immunoterapia, w której stymuluje się elementy układu odpornościowego do zwalczania komórek nowotworowych [57]. Koncepcje wykorzystania naturalnych mechanizmów obronnych organizmu do walki z nowotworem są rozważane już od dłuższego czasu, jednak możliwości zastosowania takiego podejścia terapeutycznego były ograniczone ze względu na wykształconą przez komórki nowotworowe zdolność do unikania rozpoznania i eliminacji przez układ odpornościowy. Dzięki zrozumieniu mechanizmów molekularnych tolerancji immunologicznej komórek nowotworowych doszło do ogromnego postępu w dziedzinie terapii immunologicznej nowotworów [58,59]. Obecnie opracowywane są syntetyczne, spersonalizowane szczepionki nowotworowe, które wykorzystuje się do immunizacji antygenami nowotworowymi i wywołania odpowiedzi immunologicznej przeciwko komórkom nowotworowym. Kluczową kwestią w terapiach immunologicznych jest wzmocnienie odpowiedzi komórkowej zależnej od limfocytów T cytotoksycznych (limfocyty Tc), które są głównymi komórkami układu immunologicznego odpowiedzialnymi za rozpoznanie i zwalczanie komórek nowotworowych [57,59]. Dużą nadzieją w leczeniu nowotworów stają się również tzw. terapie celowane, które opierają się na molekularnym podłożu kancerogenezy i wykorzystują specyficzne cząsteczki sygnałowe ukierunkowane na określone elementy ścieżki sygnałowej, takie jak enzymy, receptory czynników wzrostowych i cząsteczki sygnałowe [60].

\section{ZASTOSOWANIE TERAPEUTYCZNE NISKOCZĄSTECZKOWYCH INHIBITORÓW PERK}

\section{ZASTOSOWANIE NISKOCZACSTECZKOWYCH INHIBITORÓW PERK W LECZENIU CHORÓB NEURODEGENERACYJNYCH}

Istnieją liczne doniesienia, iż patogeneza chorób neurodegeneracyjnych jest ściśle skorelowana z zaburzeniami na poziomie molekularnym. W warunkach stresu ER, towarzyszącym komórkom neuronalnym, uruchamiany jest szlak sygnałowy UPR zależny od PERK. Wykazano, iż aktywacja szlaku sygnałowego UPR jest bezpośrednią przyczyną inicjacji procesu chorobowego w przypadku takich chorób neurodegeneracyjnych jak: AD, PD, HD, choroba prionowa, postępujące porażenie nadjądrowe (ang. Progressive Supranuclear Palsy, PSP) oraz otępienie czołowo-skroniowe (ang. Frontotemporal Dementia, FTD). Zatem postuluje się, iż zastosowanie niskocząsteczkowych inhibitorów szlaku UPR zależnego od kinazy PERK może stanowić innowacyjną, efektywniejszą terapię $\mathrm{w}$ leczeniu chorób neurodegeneracyjnych. [61,62]. Obiecujące dla rozwoju nowych terapii chorób neurodegeneracyjnych są badania dotyczące szlaku PERK-eIF2a, ze względu na jego pro-apoptotyczny aspekt, promujący śmierć komórek nerwowych [7]. Niskocząsteczkowy inhibitor PERK (GSK2606414) zastosowano w leczeniu myszy z chorobą prionową $[63,64]$. W przebiegu choroby prionowej akumulowane jest nieprawidłowo sfałdowa- 
Tabela 1. Inhibitory w szlaku zależnym od UPR jako potencjalne leki przeciwnowotworowe. Na podstawie [69], zmienione.

\begin{tabular}{|c|c|c|}
\hline Inhibitor & Mechanizm działania & Typ nowotworu/linie komórkowe \\
\hline GSK2606414 & p-PERK $\downarrow$, p-elF2a $\downarrow$ & Szpiczak mnogi \\
\hline GSK2656157 & p-PERK $\downarrow$, p-elF $2 a \downarrow$ & Szpiczak mnogi \\
\hline Bortezomib (inhibitor proteaosomu) & GRP78 $\uparrow, \mathrm{CHOP} \uparrow, \mathrm{JNK} \uparrow, \mathrm{p}-\mathrm{eIF} 2 \mathrm{a} \downarrow$ & Rak trzustki \\
\hline Sal003 (inhibitor fosfatazy fosfo-eif2a) & $\mathrm{p}-\mathrm{elF} 2 \mathrm{a} \uparrow$ & Glejak \\
\hline Sorafenib (inhibitor kinaz tyrozynowych) & $\mathrm{CHOP} \uparrow \mathrm{GADD} 34 \uparrow ; \mathrm{p}-\mathrm{PERK} \uparrow ; \mathrm{p}-\mathrm{elF} 2 \mathrm{a} \uparrow$ & L-428, L-1236, KM-H2 \\
\hline STF-083010 & IRE1 $\downarrow$ & Szpiczak mnogi \\
\hline Kwercetyna (inhibitor kinaz białkowych) & GRP78/BiP $\uparrow$, ATF4 $\uparrow$, IRE1 $\uparrow$ ATF6 $\uparrow$ & PC3 \\
\hline
\end{tabular}

ne białko prionu (ang. prion protein, Prp), które generowane jest w wyniku replikacji prionów. Nagromadzenie Prp prowadzi do nadmiernej aktywacji ścieżki UPR, związanej z PERK oraz eIF2a, co skutkuje niewydolnością translacyjną najważniejszych białek synaptycznych, a w konsekwencji śmiercią komórek nerwowych. Podanie zwierzętom doświadczalnym inhibitora GSK2606414 spowodowało obniżenie poziomu fosforylacji PERK oraz eIF2a oraz przywróciło prawidłową syntezę białek w komórkach tkanki nerwowej mózgu. Efektem leczenia było zahamowanie objawów choroby pomimo dalszej replikacji prionów $[62,63]$. Podobne efekty udało się otrzymać w leczeniu modelu FTD u transgenicznych myszy z mutacją P301L, wykazujących nadekspresję ludzkiego białka tau. Dowiedziono, iż u zwierząt doświadczalnych również dochodzi do silnej aktywacji ścieżki indukowanej przez PERK i zahamowania translacji, co jest ściśle powiązane $\mathrm{z}$ inicjacją procesów neurodegeneracyjnych, a w rezultacie apoptozą komórek neuronalnych w obrębie hipokampu oraz postępującym upośledzeniem pamięci. Zastosowanie inhibitora GSK2606414 u myszy z mutacją P301L przyczyniło się do zmniejszenia poziomu fosforylacji białek PERK oraz eIF2a, jak również obniżenia ekspresji białka ATF4. Ponadto wykazano znaczący spadek neurotoksycznego białka tau oraz przywrócenie prawidłowej syntezy białek, jak również zahamowanie procesu neurodegeneracyjnego oraz zmniejszenie objawów klinicznych FTD $[62,65]$.

\section{ZASTOSOWANIE NISKOCZĄSTECZKOWYCH \\ INHIBITORÓW PERK W LECZENIU \\ CHORÓB NOWOTWOROWYCH}

Szlak indukowany stresem ER odgrywa także istotną rolę $\mathrm{w}$ przebiegu chorób nowotworowych i może być aktywowany w przebiegu takich nowotworów jak rak piersi, płuc, glejak oraz rak szyjki macicy [66]. Wykazano, iż w komórkach nowotworowych gromadzenie nieprawidłowo sfałdowanych białek, a w rezultacie aktywacja stresu ER wynika przede wszystkim z hipoksji, zaburzeń w gospodarce wapnia, czy niedoboru substancji odżywczych $[8,66,67]$. Chociaż PERK może promować apoptozę, co faktycznie ma miejsce przy niektórych typach nowotworów i może być konieczne dla skutecznej chemioterapii, to przedłużająca się aktywacja PERK może mieć negatywny wpływ na leczenie i wykazywać działanie pro-adaptacyjne dla dalszego wzrostu guza [8,67]. Stopień aktywności PERK w przebiegu chorób nowotworowych może być zależny od tkanki, w której umiejscowiony jest guz, a także stadium nowotworu. Ponadto rola PERK w progresji guza jest w znacznej mierze zależna od koordynacji między pozostałymi elementami szlaku UPR. Wiele dowodów wskazuje jednak, iż aktywność PERK przyczynia się do niestabilności genomu, chemooporności guza, jak również lepszej adaptacji komórek nowotworowych do mikrośrodowiska [8]. Konstytucyjna aktywacja PERK i fosforylacja eIF2a może przeciwdziałać cytotoksycznemu działaniu TNFa, a także negatywnie wpływać na leczenie bortezomibem [67]. Co więcej, wzrost aktywności PERK związany jest z syntezą onkogennego białka c-Myc. PERK odgrywa także istotną rolę $\mathrm{w}$ angiogenezie, progresji guza i przerzutowaniu, dlatego inhibicja tego białka może okazać się skuteczną strategią terapeutyczną [8]. Udało się wykazać inhibicję PERK przy pomocy GSK2606414 w dwóch liniach nowotworowych (SH-SY5Y oraz HT-29), co jest obiecującym wynikiem dla wykorzystania niskocząsteczkowych inhibitorów PERK w leczeniu chorób nowotworowych [68]. Działanie inhibitora GSK2606414 zostało również potwierdzone $\mathrm{w}$ badaniach in vivo u myszy $\mathrm{z}$ przeszczepem ludzkiego guza trzustki oraz w modelu szpiczaka mnogiego u myszy z niedoborem odporności, u których po podaniu GSK2606414 doszło do zahamowania rozrostu nowotworu. Skuteczność terapii niskocząsteczkowym inhibitorem PERK w badaniach in vivo wynika prawdopodobnie z jego wpływu na zmniejszenie gęstości naczyń krwionośnych oraz perfuzji naczyniowej [66,69]. Druga generacja niskocząsteczkowych inhibitorów PERK wykazała jeszcze lepsze efekty terapeutyczne, a podanie inhibitora GSK2656157 wiązało się $\mathrm{z}$ hamowaniem wzrostu guza w sposób zależny od podawanej dawki (Tab. 1) [8].

\section{EFEKTYWNOŚĆ DOTYCHCZAS OPRACOWANYCH INHIBITORÓW PERK}

Pomimo licznych przesłanek, iż zastosowanie dotychczas opracowanych inhibitorów PERK może prowadzić do korzystnych efektów terapeutycznych, inhibitory zostały wycofane z dalszych badań klinicznych ze względu na powodowanie licznych skutków ubocznych. Długotrwałe hamowanie szlaku UPR zależnego od PERK wywołało działanie cytotoksyczne w stosunku do komórek prawidłowych trzustki, a w rezultacie prowadziło do szybkiej utraty masy ciała, hipoglikemii, a następnie rozwoju cukrzycy u zwierząt doświadczalnych $[7,8,70]$. Poziom PERK musi podlegać ścisłej kontroli również ze względu na fakt, iż podtrzymanie 
pewnych rozgałęzień szlaku UPR, takich jak szlak indukowany ATF6, może mieć pozytywny wpływ na neuroprotekcję poprzez indukcję degradacji nieprawidłowo sfałdowanych białek oraz regulację białek opiekuńczych [7]. Całkowite zahamowanie PERK mogłoby uniemożliwić prawidłową odpowiedź komórek na stres. $Z$ tego względu konieczne jest opracowanie skutecznej, a jednocześnie nieszkodliwej dawki inhibitora oraz dostosowanie czasu trwania leczenia. Zmniejszenie skutków ubocznych terapii przy pomocy inhibicji PERK możliwe jest również przez zmodyfikowanie inhibitora tak, aby jego aktywność była ograniczona jedynie do tkanki objętej zmianami chorobowymi. Badania wskazują, iż w przypadku chorób neurodegeneracyjnych istotne jest także szybkie rozpoczęcie terapii, ponieważ w wielu przypadkach leczenie za pomocą inhibitora PERK okazywało się nieskuteczne, jeśli zastosowano je na późniejszych stadiach choroby, w których doszło do znacznej degeneracji neuronów [71]. Obiecujące dla dalszego rozwoju terapii inhibitorami PERK są doniesienia o wpływie interferonów typu I (IFN) na toksyczność trzustkową wywołaną hamowaniem PERK. U myszy pozbawionych genu PERK dochodziło do zwiększenia syntezy receptora interferonu IFNAR1 (ang. interferon-alpha/beta receptor alpha chain) w trzustce. Natomiast u myszy z nokautem genu IFNAR1, a także w przypadku, gdy IFNAR1 blokowano specyficznym przeciwciałem, zaobserwowano osłabienie toksyczności trzustkowej spowodowanej inaktywacją PERK i zwiększenie liczby endokrynnych komórek trzustki [72].

\section{PODSUMOWANIE}

Stres ER stanowi ważny czynnik etiologiczny wielu chorób człowieka, w tym schorzeń związanych z rozwojem stanu zapalnego i stresu oksydacyjnego, chorób metabolicznych, neurodegeneracyjnych oraz nowotworowych i należy go uwzględnić $w$ dalszych badaniach dotyczących tych schorzeń. Szlak UPR, ze względu na swoją dualistyczna rolę, wiąże się z aktywacją procesów, które mogą zwiększać adaptację komórek do warunków stresu ER oraz aktywować mechanizmy związane ze śmiercią komórek, co jest istotne z punktu widzenia zarówno terapii chorób neurodegeneracyjnych jak i nowotworowych. Rozwój skuteczniejszych terapii chorób nowotworowych i neurodegeneracyjnych jest szczególnie istotny z racji niepokojących statystyk dotyczących zachorowalności oraz śmiertelności, a także z powodu niskiej skuteczności obecnie stosowanych metod leczenia. Na szczególną uwagę zasługują ścieżki sygnałowe szlaku UPR zależne od PERK, których inhibicja wykazywała pozytywne efekty terapeutyczne zarówno $\mathrm{w}$ badaniach in vitro, jak i in vivo na modelach zwierzęcych. Ze względu na możliwe skutki uboczne zastosowania niskocząsteczkowych inhibitorów PERK konieczne jest przeprowadzenie dalszych analiz, które pozwoliłyby na wyeliminowanie tego problemu oraz opracowanie nowatorskiej strategii terapeutycznej.

\section{PIŚMIENNICTWO}

1. Smith M, Wilkinson S (2017) ER homeostasis and autophagy. Essays Biochem 61: 625-635

2. Rozpedek W, Pytel D, Nowak-Zdunczyk A, Lewko D, Wojtczak R, Diehl JA, Majsterek I (2018) Breaking the DNA damage response via serine/threonine kinase inhibitors to improve cancer treatment. Curr Med Chem: doi: 10.2174/0929867325666180117102233
3. Turoverov KK, Kuznetsova IM, Uversky VN (2010) The protein kingdom extended: ordered and intrinsically disordered proteins, their folding, supramolecular complex formation, and aggregation. Prog Biophys Mol Biol 102: 73-84

4. Klus P, Cirillo D, Botta Orfila T, Gaetano Tartaglia G (2015) Neurodegeneration and cancer: Where the disorder prevails. Sci Rep 5: 15390

5. Wang S, Kaufman RJ (2012) The impact of the unfolded protein response on human disease. J Cell Biol 197: 857-67

6. Martinez G, Duran-Aniotz C, Cabral-Miranda F, Vivar JP, Hetz C (2017) Endoplasmic reticulum proteostasis impairment in aging. Aging Cell 16: 615-623

7. Halliday M, Hughes D, Mallucci GR (2017) Fine-tuning PERK signaling for neuroprotection. J Neurochem 142: 812-826

8. Bu Y, Diehl JA (2016) PERK integrates oncogenic signaling and cell survival during cancer development. J Cell Physiol 231: 2088-96

9. Duraes F, Pinto M, Sousa E (2018) Old drugs as new treatments for neurodegenerative diseases. Pharmaceuticals (Basel) 11: pii: E44

10. Torre LA, Bray F, Siegel RL, Ferlay J, Lortet-Tieulent J, Jemal A (2015) Global cancer statistics, 2012. CA Cancer J Clin 65: 87-108

11. Erkkinen MG, Kim MO, Geschwind MD (2018) Clinical neurology and epidemiology of the major neurodegenerative diseases. Cold Spring Harb Perspect Biol 10: pii: a033118

12. Ferlay J, Soerjomataram I, Dikshit R, Eser S, Mathers C, Rebelo M, Parkin DM, Forman D, Bray F (2015) Cancer incidence and mortality worldwide: sources, methods and major patterns in GLOBOCAN 2012. Int J Cancer 136: E359-86

13. Afroze D, Kumar A (2017) ER stress in skeletal muscle remodeling and myopathies. FEBS J 286: 379-398

14. Chaudhari N, Talwar P, Parimisetty A, Lefebvre d'Hellencourt C, Ravanan P (2014) A molecular web: endoplasmic reticulum stress, inflammation, and oxidative stress. Front Cell Neurosci 8: 213

15. Rozpedek W, Pytel D, Mucha B, Leszczynska H, Diehl JA, Majsterek I (2016) The role of the PERK/eIF2alpha/ATF4/CHOP signaling pathway in tumor progression during endoplasmic reticulum stress. Curr Mol Med 16: 533-44

16. Deegan S, Saveljeva S, Gorman AM, Samali A (2013) Stress-induced self-cannibalism: on the regulation of autophagy by endoplasmic reticulum stress. Cell Mol Life Sci 70: 2425-41

17. Michalak M, Robert Parker JM, Opas M (2002) $\mathrm{Ca}^{2+}$ signaling and calcium binding chaperones of the endoplasmic reticulum. Cell Calcium 32: 269-78

18. Wang M, Kaufman RJ (2014) The impact of the endoplasmic reticulum protein-folding environment on cancer development. Nat Rev Cancer 14: 581-97

19. Kaneko M, Imaizumi K, Saito A, Kanemoto S, Asada R, Matsuhisa K, Ohtake Y (2017) ER stress and disease: toward prevention and treatment. Biol Pharm Bull 40: 1337-1343

20. Cybulsky AV (2017) Endoplasmic reticulum stress, the unfolded protein response and autophagy in kidney diseases. Nat Rev Nephrol 13: 681-696

21. Rashid HO, Yadav RK, Kim HR, Chae HJ (2015) ER stress: Autophagy induction, inhibition and selection. Autophagy 11: 1956-1977

22. Rozpedek W, Markiewicz L, Diehl JA, Pytel D, Majsterek I (2015) Unfolded protein response and PERK kinase as a new therapeutic target in the pathogenesis of Alzheimer's disease. Curr Med Chem 22: 3169-84

23. Fan Y, Lee K, Wang N, He JC (2017) The role of endoplasmic reticulum stress in diabetic nephropathy. Curr Diab Rep 17: 17

24. Salminen A, Kauppinen A, Suuronen T, Kaarniranta K, Ojala J (2009) ER stress in Alzheimer's disease: a novel neuronal trigger for inflammation and Alzheimer's pathology. J Neuroinflammation 6: 41

25. Rozpedek W, Pytel D, Diehl JA, Majsterek I (2016) Niskocząsteczkowe inhibitory szlaku zależnego od kinazy PERK jako nowa, molekularna strategia terapeutyczna w leczeniu choroby Alzheimera. Pol Merkur Lekarski 241: 5-10 
26. Rozpedek W, Markiewicz L, Diehl JA, Pytel D, Majsterek I (2015) Rola mechanizmu adaptacyjnej odpowiedzi na stres w patogenezie chorób neurodegeneracyjnych, nowotworowych oraz cukrzycy typu 2. Pol Merkur Lekarski 39: 393-7

27. Endres K, Reinhardt S (2013) ER-stress in Alzheimer's disease: turning the scale? Am J Neurodegener Dis 2: 247-65

28. Hashimoto S, Saido TC (2018) Critical review: involvement of endoplasmic reticulum stress in the aetiology of Alzheimer's disease. Open Biol 8: pii: 180024

29. Mollereau B, Manie S, Napoletano F (2014) Getting the better of ER stress. J Cell Commun Signal 8: 311-21

30. Elmore S (2007) Apoptosis: a review of programmed cell death. Toxicol Pathol 35: 495-516

31. Malhotra JD, Kaufman RJ (2011) ER stress and its functional link to mitochondria: role in cell survival and death. Cold Spring Harb Perspect Biol 3: a004424

32. Nishitoh H (2012) CHOP is a multifunctional transcription factor in the ER stress response. J Biochem 151: 217-9

33. Rozpedek W, Nowak A, Pytel D, Diehl JA, Majsterek I (2017) Molecular basis of human diseases and targeted therapy based on small-molecule inhibitors of ER stress-induced signaling pathways. Curr Mol Med 17: 118-132

34. Rozpedek W, Nowak A, Pytel D, Lewko D, Diehl JA, Majsterek I (2016) The role of the Amyloid Precursor Protein mutations and PERK-dependent signaling pathways in the pathogenesis of Alzheimer's disease. Folia Biologica et Oecologica 12: 48-59

35. Piguet F, Alves S, Cartier N (2017) Clinical gene therapy for neurodegenerative diseases: past, present, and future. Hum Gene Ther 28 988-1003

36. Rasool M, Malik A, Qureshi MS, Manan A, Pushparaj PN, Asif M, Qazi MH, Qazi AM, Kamal MA, Gan SH, Sheikh IA (2014) Recent updates in the treatment of neurodegenerative disorders using natural compounds. Evid Based Complement Alternat Med 2014: 979730

37. Oertel W, Schulz JB (2016) Current and experimental treatments of Parkinson disease: A guide for neuroscientists. J Neurochem 139 Suppl 1: 325-337

38. Valera E, Spencer B, Masliah E (2016) Immunotherapeutic approaches targeting amyloid-beta, alpha-synuclein, and Tau for the treatment of neurodegenerative disorders. Neurotherapeutics 13: 179-89

39. Ghosh R, Tabrizi SJ (2017) Gene suppression approaches to neurodegeneration. Alzheimers Res Ther 9: 82

40. Nielsen TT, Nielsen JE (2013) Antisense gene silencing: therapy for neurodegenerative disorders? Genes (Basel) 4: 457-84

41. Maraganore DM (2011) Rationale for therapeutic silencing of alpha-synuclein in Parkinson's disease. J Mov Disord 4: 1-7

42. Spencer B, Michael S, Shen J, Kosberg K, Rockenstein E, Patrick C, Adame A, Masliah E (2013) Lentivirus mediated delivery of neurosin promotes clearance of wild-type alpha-synuclein and reduces the pathology in an alpha-synuclein model of LBD. Mol Ther 21: 31-41

43. Devi L, Ohno M (2015) A combination Alzheimer's therapy targeting BACE1 and neprilysin in 5XFAD transgenic mice. Mol Brain 8: 19

44. Danzer KM, Ruf WP, Putcha P, Joyner D, Hashimoto T, Glabe C, Hyman BT, McLean PJ (2011) Heat-shock protein 70 modulates toxic extracellular alpha-synuclein oligomers and rescues trans-synaptic toxicity. FASEB J 25: 326-36

45. Caruana M, Hogen T, Levin J, Hillmer A, Giese A, Vassallo N (2011) Inhibition and disaggregation of alpha-synuclein oligomers by natural polyphenolic compounds. FEBS Lett 585: 1113-20

46. Siddiqui M, Rajkumar SV (2012) The high cost of cancer drugs and what we can do about it. Mayo Clin Proc 87: 935-43

47. Mahmood SS, Nohria A (2016) Cardiovascular complications of cranial and neck radiation. Curr Treat Options Cardiovasc Med 18: 45

48. Colagiuri B, Dhillon H, Butow PN, Jansen J, Cox K, Jacquet J (2013) Does assessing patients' expectancies about chemotherapy side effects influence their occurrence? J Pain Symptom Manage 46: 275-81
49. Kuipers EJ, Grady WM, Lieberman D, Seufferlein T, Sung JJ, Boelens PG, van de Velde CJ, Watanabe T (2015) Colorectal cancer. Nat Rev Dis Primers 1: 15065

50. Sebesta EM, Anderson CB (2017) The surgical management of prostate cancer. Semin Oncol 44: 347-357

51. Pietzak EJ, Eastham JA (2016) Neoadjuvant treatment of high-risk, clinically localized prostate cancer prior to radical prostatectomy. Curr Urol Rep 17: 37

52. Wyld L, Audisio RA, Poston GJ (2015) The evolution of cancer surgery and future perspectives. Nat Rev Clin Oncol 12: 115-24

53. Barbu CG, Arsene AL, Florea S, Albu A, Sirbu A, Martin S, Nicolae AC, Burcea-Dragomiroiu GTA, Popa DE, Velescu BS, Dumitrescu IB, Mitrea N, Draganescu D, Lupuliasa D, Spandidos DA, Tsatsakis AM, Dragoi CM, Fica S (2017) Cardiovascular risk assessment in osteoporotic patients using osteoprotegerin as a reliable predictive biochemical marker. Mol Med Rep 16: 6059-6067

54. van Hagen P, Hulshof MC, van Lanschot JJ, Steyerberg EW, van Berge Henegouwen MI, Wijnhoven BP, Richel DJ, Nieuwenhuijzen GA, Hospers GA, Bonenkamp JJ, Cuesta MA, Blaisse RJ, Busch OR, ten Kate FJ, Creemers GJ, Punt CJ, Plukker JT, Verheul HM, Spillenaar Bilgen EJ, van Dekken H, van der Sangen MJ, Rozema T, Biermann K, Beukema JC, Piet AH, van Rij CM, Reinders JG, Tilanus HW, van der Gaast A, Group C (2012) Preoperative chemoradiotherapy for esophageal or junctional cancer. N Engl J Med 366: 2074-84

55. Cooper S, Spiro SG (2006) Small cell lung cancer: treatment review. Respirology 11: 241-8

56. Draganescu M, Carmocan C (2017) Hormone therapy in breast cancer. Chirurgia (Bucur) 112: 413-417

57. Kakimi K, Karasaki T, Matsushita H, Sugie T (2017) Advances in personalized cancer immunotherapy. Breast Cancer 24: 16-24

58. Yang Y (2015) Cancer immunotherapy: harnessing the immune system to battle cancer. J Clin Invest 125: 3335-3337

59. Stambrook PJ, Maher J, Farzaneh F (2017) Cancer immunotherapy: whence and whither. Mol Cancer Res 15: 635-650

60. Tsimberidou AM (2015) Targeted therapy in cancer. Cancer Chemother Pharmacol 76: 1113-32

61. Martin-Jimenez CA, Garcia-Vega A, Cabezas R, Aliev G, Echeverria V, Gonzalez J, Barreto GE (2017) Astrocytes and endoplasmic reticulum stress: A bridge between obesity and neurodegenerative diseases. Prog Neurobiol 158: 45-68

62. Radford H, Moreno JA, Verity N, Halliday M, Mallucci GR (2015) PERK inhibition prevents tau-mediated neurodegeneration in a mouse model of frontotemporal dementia. Acta Neuropathol 130: 633-42

63. Moreno JA, Halliday M, Molloy C, Radford H, Verity N, Axten JM, Ortori CA, Willis AE, Fischer PM, Barrett DA, Mallucci GR (2013) Oral treatment targeting the unfolded protein response prevents neurodegeneration and clinical disease in prion-infected mice. Sci Transl Med 5: 206ra138

64. Rozpedek W, Pytel D, Popławski T, Walczak A, Gradzik K, Wawrzynkiewicz A, Wojtczak R, Mucha B, Diehl JA, Majsterek I (2019) Inhibition of the PERK-dependent Unfolded Protein Response signaling pathway involved in the pathogenesis of Alzheimer's disease. Current Alzheimer Research, in press

65. Smith HL, Mallucci GR (2016) The unfolded protein response: mechanisms and therapy of neurodegeneration. Brain 139: 2113-21

66. Atkins C, Liu Q, Minthorn E, Zhang SY, Figueroa DJ, Moss K, Stanley TB, Sanders B, Goetz A, Gaul N, Choudhry AE, Alsaid H, Jucker BM, Axten JM, Kumar R (2013) Characterization of a novel PERK kinase inhibitor with antitumor and antiangiogenic activity. Cancer Res 73: 1993-2002

67. Salaroglio IC, Panada E, Moiso E, Buondonno I, Provero P, Rubinstein M, Kopecka J, Riganti C (2017) PERK induces resistance to cell death elicited by endoplasmic reticulum stress and chemotherapy. Mol Cancer 16: 91

68. Rozpedek W, Pytel D, Dziki L, Nowak A, Dziki A, Diehl JA, Majsterek I (2017) Inhibition of PERK-dependent pro-adaptive signaling path- 
way as a promising approach for cancer treatment. Pol Przegl Chir 89: 7-10

69. Walczak A, Gradzik K, Kabzinski J, Przybylowska-Sygut K, Majsterek I (2019) The role of the ER-induced UPR pathway and the efficacy of its inhibitors and inducers in the inhibition of tumor progression. Oxid Med Cell Longev 5729710: 15

70. Hughes D, Mallucci GR (2018) The unfolded protein response in neurodegenerative disorders - therapeutic modulation of the PERK pathway. FEBS J 286: 342-355
71. Ma T, Klann E (2014) PERK: a novel therapeutic target for neurodegenerative diseases? Alzheimers Res Ther 6: 30

72. Yu Q, Zhao B, Gui J, Katlinski KV, Brice A, Gao Y, Li C, Kushner JA, Koumenis C, Diehl JA, Fuchs SY (2015) Type I interferons mediate pancreatic toxicities of PERK inhibition. Proc Natl Acad Sci U S A 112: 15420-15425

\section{Potential therapeutic application of PERK inhibitors}

\section{Justyna Basak ${ }^{1}$, Wioletta Rozpędek ${ }^{1}$, Dariusz Pytel $^{2}$, Ireneusz Majsterek ${ }^{1}$}

${ }^{1}$ Department of Clinical Chemistry and Biochemistry, Medical University of Lodz, Lodz, Poland

${ }^{2}$ Department of Biochemistry and Molecular Biology, Hollings Cancer Center, Medical University of South Carolina, Charleston, S.C. 29425, USA

${ }^{\square}$ To whom the correspondence should be addressed

Key words: ER stress, UPR, PERK, cancer, neurodegenerative disorders, PERK inhibitors

\section{ABSTRACT}

Recent studies aimed at understanding the molecular mechanisms of human disease indicate that in the pathogenesis of many metabolic disorders, including inflammatory processes, aging of the organism, as well as cancer and neurodegenerative disorders, endoplasmic reticulum stress plays a significant role that is associated with the accumulation of misfolded proteins in the lumen of endoplasmic reticulum. In response to endoplasmic reticulum stress, the unfolded protein response pathway, that has a dualistic role, is induced. The unfolded protein response can restore endoplasmic reticulum homeostasis by degradation of unfolded proteins, inhibition of translation, and mobilization of chaperons, but it can also promote apoptosis when endoplasmic reticulum stress is prolonged. The unfolded protein response signaling pathways may be activated via three transmembrane receptors such as: PERK, IRE1 and ATF6. The most promising for development of new therapies of many human diseases, in particular cancer and neurodegeneration is PERK pathway, that inhibition shows positive therapeutic effects both in in vitro and in vivo studies. 